\title{
PIERRE BAYLE E A REFLEXÃO SOBRE A IMAGEM DO ATEU VIRTUOSO NA MODERNIDADE
}

\author{
Marcelo de Sant'Anna Alves Primo ${ }^{1}$ \\ Universidade Federal de Sergipe (UFS) \\ https://orcid.org/0000-0002-7406-5371
}

\begin{abstract}
RESUMO:
Circunscrevendo o âmbito no qual o ateísmo pode ser compreendido, a saber, na esfera dos costumes, convenções religiosas, políticas e teológicas, e até mesmo no campo dos temperamentos e caracteres, desde os Pensées diverses sur la comète até a Continuation des Pensées sur la comète e a Réponse aux quéstions d'un Provincial Bayle erige, fundamenta e radicaliza o vínculo entre ateísmo e virtude, entendendo aqui ateísmo sob um enfoque de caráter prático, ou seja, em relação à atitude daqueles que vivem como se um deus não existisse, minimizando o valor de sua eficácia sobre a conduta humana. Porém, tal postura não é menos dotada de virtude, uma vez que se entenda tal termo como uma perpétua disposição para cumprir determinados atos morais e tendo como objeto os atos da vida prática, como por exemplo, justiça, honestidade, coragem, amizade, entre outros.
\end{abstract}

PALAVRAS-CHAVE: Bayle; Ateísmo; Moral; Virtude.

\section{PIERRE BAYLE AND THE REFLECTION ON THE IMAGE OF THE VIRTUOUS ATHEIST IN MODERNITY}

\begin{abstract}
:
Circumscribing the scope in which atheism can be understood, namely, in the sphere of customs, religious, political and theological conventions, and even in the field of temperaments and characters, from Pensées diverses sur la comète to Continuation des Pensées sur la comète, and the Réponse aux quéstions d'un Provincial Bayle erects, substantiates and radicalizes the link between atheism and virtue, understanding here atheism under a practical approach, that is, in relation to the attitude of those who live as if a god did not exist, minimizing the value of its effectiveness over human conduct. However, such a position is no less endowed with virtue, once such a term is understood as a perpetual disposition to perform certain moral acts and having as purpose the acts of practical life, such as justice, honesty, courage, friendship, among others.
\end{abstract}

KEYWORDS: Bayle; Atheism; Moral; Virtue.

1 Bolsista do PNPD-CAPES/UFS. Professor colaborador do Programa de PósGraduação em Filosofia da Universidade Federal de Sergipe (UFS), Sergipe - Brasil. E-mail: marceloprimo_sp@hotmail.com

PRIMO, Marcelo de Sant'Anna Alves. Pierre Bayle e a reflexão sobre a imagem do ateu virtuoso na modernidade. Griot : Revista de Filosofia, Amargosa/Bahia, v.17, n.1, p.337-353, junho/2018. 


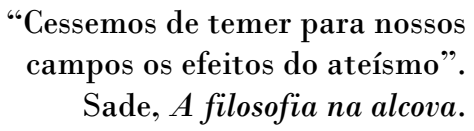

O medo de "maus" presságios proporcionado pela passagem de cometas foi mais um pretexto do que propriamente um motivo para Pierre Bayle redigir seus Pensées diverses sur la comète, uma vez que o filósofo atacará com firmeza toda sorte de superstições, bruxarias, adivinhações e presságios no decorrer da obra ${ }^{2}$. Nesse sentido, de uma crítica contundente à superstição, o filósofo de Carla faz com que a questão do ateísmo entre realmente a sério no pensamento moderno, empreendendo a sua tarefa subterrânea de corrosão na esfera da religião e da transcendência ${ }^{3}$. Circunscrevendo o âmbito no qual o ateísmo pode ser compreendido, a saber, na esfera dos costumes, convenções religiosas, políticas e teológicas, e até mesmo no campo dos temperamentos e caracteres, desde os Pensées diverses até a Continuation des Pensées sur la comète e a Réponse aux quéstions d'un Provincial Bayle erige, fundamenta e radicaliza o vínculo entre ateísmo e virtude, entendendo aqui ateísmo sob um enfoque de caráter prático, ou seja, em relação à atitude daqueles que vivem como se um deus não existisse, minimizando o valor de sua eficácia sobre a conduta humana. Porém, tal postura não é menos dotada de virtude, uma vez que se entenda tal termo como uma perpétua disposição para cumprir determinados atos morais e tendo como objeto os atos da vida prática, como por exemplo, justiça, honestidade, coragem, amizade, entre outros. De tais definições, surge no horizonte a figura do ateu virtuoso em meados do século XVII, ou seja, aquele que estabelecendo uma relação imediata entre razão e virtude, não crendo em uma providência nem na imortalidade da alma, tampouco em recompensas post-mortem, deposita sua confiança nas próprias leis que promulgou, e fazendo das mesmas a única condição para viver e para a sua felicidade. Daí duas conclusões cabais: primeiramente, a moral natural é absolutamente suficiente para assumir a virtude e a vida social; a outra, decorrente da primeira, é que o ateísmo não é prejudicial à vida civil ${ }^{4}$.

\footnotetext{
2 Para Pierre-François Moreau, ao constatar o resultado do acontecimento, isto é, da passagem do cometa, Bayle "vai substituir sua explicação supersticiosa por uma antropologia da superstição." MOREAU, Pierre-François, "Les sept raisons des Pensées diverses", In: Pierre Bayle: la foi dans le doute. Génève: Labor et fides, 1995, p.22. Por sua vez, para Alain Niderst, a redação dos Pensées diverses poderia ser mais que um mero pretexto: "O cometa é somente um pretexto ao qual o autor recorreu após ter terminado a sua obra, ou é o ponto de partida do qual ele se afastou sem escrúpulos?" In: BAYLE, Pierre. Oeuvres diverses. Paris: Éditions Sociales, 1971, p. 53.

3 Ver a metáfora do próprio Bayle do poder corrosivo da razão, no verbete "Acosta", nota G, do Dictionnaire. Segundo Delpla e Robert, "a metáfora médica e biológica das partículas corrosivas exprime esta ambivalência da razão aos olhos de Bayle: antes de tudo, ele reconhece nela uma função terapêutica, a de um instrumento crítico indispensável à busca da verdade, recusando todo argumento de autoridade, todo preconceito, toda solução de complacência, escrutando e dissecando cada argumento de uma demonstração." DELPLA, I. e DE ROBERT, P. "Introduction”, in: DELPLA, Isabelle, ROBERT, Philippe de. La raison corrosive: études sur la pensée critique de Pierre Bayle. Paris: Honoré Champion, 2003.

4 Tese que escandalizara Frédéricde Dohna. Ao final de uma carta à Bayle, de junho de 1683, ele diz: "Mas eu estou perdido aí onde bastaria repetir que estou muito persuadido que a idolatria é ainda mais criminosa perante Deus do que o ateísmo, mas que, entretanto, é um obstáculo muito grande à integridade da vida, mesmo se não tivesse o cristianismo." In: BAYLE, Pierre. Correspondance, Tome III. Publiées et annotées par Élisabeth Labrousse, Hubert Bost et alli. Oxford: Voltaire Foundation,
}

PRIMO, Marcelo de Sant'Anna Alves. Pierre Bayle e a reflexão sobre a imagem do ateu virtuoso na modernidade. Griot : 
Tais considerações preliminares permitem agora adentrar no núcleo duro da questão: o paradoxo ou o suposto paradoxo do ateu virtuoso ${ }^{5}$. Bayle diz nos Pensées diverses:

\begin{abstract}
Assim sendo, posso passar a fazer o paralelo da idolatria e do ateísmo e mostrar que a idolatria é, pelo menos, tão abominável como o ateísmo, porque não tenho necessidade que este paradoxo seja verdadeiro. Eu o ouvi sustentado por um dos mais hábeis homens da França e que é tão bom cristão quanto eu o conheço. Permiteis relatar-vos uma parte de suas razões e parafraseá-las ou comentar segundo o que julgarei a propósito (2007, p. 257; OD III [PD], p. 75b, tradução nossa).
\end{abstract}

Eis o ponto de partida: a comparação da idolatria com o ateísmo, apurar equilibradamente e passo a passo seus prós e contras e ver qual dois é o menos aberrante ${ }^{6}$. Bayle é prudente, pois afirma que o conúbio entre ateísmo e virtude pode ser hipotético, não se preocupando com a sua veracidade, porém, escandaliza, pois diz que ouviu tal afirmação de um religioso irreprovável em sua conduta. Caberia a ele somente "parafrasear" uma parte dos motivos que levou o religioso a sustentar a figura do ateu virtuoso e tecer algum comentário a respeito ${ }^{7}$.

Após fazer inúmeras considerações sobre a natureza dos cometas, Bayle dá um contorno mais preciso ao seu propósito de investigar se o ateísmo pode ser execrado e a idolatria digna de ser louvada, uma vez que os céus deram um "aviso" para a concretização de tal empreitada. Entretanto, se é fato, se é comprovado pela experiência que religiosos cometem todo tipo de crimes em nome de uma crença, de uma doutrina ou de seus anseios particulares, o ateu virtuoso é uma figura conjectural, sendo vista como um paradoxo sem correspondente algum na ordem dos

2004, lettre 223, p. 367, tradução nossa.

5 Para Mori, o que por vezes é chamado "o paradoxo do ateu virtuoso não é de todo um paradoxo para Bayle, mas uma consequência de seu racionalismo moral." "Baruch de Spinoza: athée vertueux, athée de système", In: Critique, savoir et érudition à la veille des Lumières: le Dictionnaire historique et critique de Pierre Bayle. Amsterdam \& Maarssen: APA-Holland University Express, 1996, p.345.

${ }^{6}$ Isto é, procedimentos de investigação que, segundo Pierre Rétat, seriam um verdadeiro deleite para Bayle: "É uma prazer para ele [Bayle] imaginar provas, paradoxos, aí tentar a sua fecundidade, de lançá-los ao público oara colocá-los à prova do pró e do contra. Somente a este respeito, os Pensées dariam lugar a um estudo apaixonante da retórica e da argumentação, que, antes de tudo, manifestaria a felicidade tão particular de jogar com o leitor e encerrá-lo em digressões, de fazer alternar os 'cursos' e as 'pausas', de agregar os desvios, e de mostrar repentinamente que se está perto do alvo." "Avertissement de la deuxième édition (1984-1994)", In: Pensées diverses sur la comète. Paris: Société dês Textes Modernes, 1994, p. 21.

7 Segundo Isabelle Delpla, o caráter, "hipotético" da figura do ateu virtuoso passa a ter um caráter mais concreto nos escritos posteriores de Bayle: "Se nos Pensées diverses, o paradoxo surge da experiência de pensamento, de uma ficção metafísica ou de uma simples possibilidade lógica no todo complexo de disjunções que estruturam a argumentação geral, nas obras ulteriores, o apelo à experiência e aos relatos de viagens dão corpo a esta conjectura. Na Continuation des pensées diverses e Les Réponses aux questions d'un provincial, o ateísmo social passa de um mundo logicamente possível a um mundo antropologicamente possível, de uma possibilidade psicológica no nível individual a uma possibilidade social no nível de uma comunidade."(1999, p.121.) Entretanto, Bayle está longe de deixar de recorrer à experiência já nos próprios Pensées diverses. Ver em particular os parágrafos $§ 46$, $\S 84, \S 89, \S \S 107-108, \S 120, \S 134, \S 141, \S 145, \S 153, \S \S 174-175, \S 180$ e $\S 263$.

PRIMO, Marcelo de Sant'Anna Alves. Pierre Bayle e a reflexão sobre a imagem do ateu virtuoso na modernidade. Griot : 
fatos. Em um primeiro momento, a associação entre ateísmo e virtude parece não ultrapassar a condição de pura hipótese:

Eu já o disse: não há anais que nos ensinem os costumes e hábitos de uma
nação mergulhada no ateísmo. Assim, não se pode refutar por experiência
a conjectura que foi feita antes a este respeito, a saber, que os ateus não
são capazes de nenhuma virtude moral e que são bestas ferozes entre as
quais há mais a temer por sua vida que entre os tigres e os leões. Mas não é
difícil ver que esta conjectura é muito incerta. Porque, visto que a
experiência nos mostra que aqueles que creem em um Paraíso e em um
Inferno são capazes de cometer toda sorte de crimes, é evidente que a
inclinação a fazer o mal não vem do que ignora a existência de Deus e que
ela não é corrigida pelo conhecimento que se adquiriu de um Deus que
pune e que recompensa (PD, 2007 , p. $311 ; O D \operatorname{III}[P D]$, pp. $93 b-94 a$,
tradução nossa).

Retomando a reflexão antes levantada a respeito do caráter conjectural da figura do ateu virtuoso ${ }^{8}$, Bayle aqui o reafirma, entendendo que o recurso à História não permite que possa ser sustentado o laço indissolúvel entre ateísmo e virtude. Contudo, um olhar mais acurado nesta passagem fará ver que a experiência, já nos Pensées diverses, permite sustentar a imagem positiva do ateísmo em termos concretos. Se por um lado, Bayle concede que não é possível recorrendo aos fatos provar que ser ateu e ser moral não é inconcebível, ele mostra pela própria experiência que ser crente e cometer más ações é o que há de mais ordinário.

A incerteza da conjectura de tal paradoxo é trazida à tona a partir do momento que é verificado e provado que fazer o mal independe do que se crê ou descrê, e tampouco sendo corrigida tal inclinação pelo conhecimento que se tem de uma divindade. Vejamos uma passagem do Eclaircissement sur les athées:

\begin{abstract}
Não há nada mais fácil que encontrar na história certos celerados, os quais as ações abomináveis fazem quase tremer os leitores: mas eram pessoas as quais mesmo as impiedades \& as blasfêmias são uma prova que eles acreditavam na divindade. Eis uma decorrência natural da doutrina constante dos teólogos, que o demônio, a mais maldosa de todas as criaturas, mas incapaz de ateísmo, é o promotor de todos os pecados do gênero humano; porque, assim sendo, é preciso que a mais ultrajante maldade do homem tenha o caráter da do Diabo, isto é, que ela esteja cojunta com a persuasão da existência de Deus (2010, p. 19, tradução nossa).
\end{abstract}

Mesmo havendo uma certa distância entre a publicação dos Pensées diverses e do Éclaircissement, Bayle mantém o mesmo ponto de vista sobre o ateísmo, mas agora afirma que não há dificuldade alguma em constatar através dos fatos históricos que as maiores aberrações humanas e a crença em um deus sempre estiveram lado a lado. Em outros termos, em Bayle a experiência é um examen, uma verificação para desconstruir determinadas opiniões enviesadas propagadas e cristalizadas em todos os tempos e lugares. Se pela experiência não é possível mostrar que existiram ateus virtuosos, é a própria experiência que mostra que tudo o que foi afirmado sobre o

${ }^{8}$ Ver $P D, \S 129$.

PRIMO, Marcelo de Sant'Anna Alves. Pierre Bayle e a reflexão sobre a imagem do ateu virtuoso na modernidade. Griot : 
ateísmo é totalmente equivocado em termos $\left.{ }^{9}: 1\right)$ históricos, pois se não há provas concretas da existência de ateus virtuosos, tampouco existem provas de seu contrário, ou seja, a existência de ateus depravados, ou que todos incorreram pelo caminho do vício; 2) filosóficos, a partir do momento que Bayle põe à prova tanto por meio da razão como pela experiência, os argumentos de seus opositores contra o ateísmo, empreendendo um exame de seus argumentos, premissas e proposições; 3) morais, a partir do momento em que afirma que moralidade nada tem a ver com o que se crê, empreendendo uma reflexão filosófica sobre diversos acontecimentos históricos para mostrar que crença religiosa e retidão nas ações nem senpre estiveram em plena consonância; 4) políticos, quando mostra que, a despeito de fenômenos naturais ocorrerem em contextos de decisões políticas importantes, em nada tais fenômenos influenciaram no curso dos fatos. Na verdade, Bayle mostra a projeção de uma crença particular que ocorre sobre certos fenômenos naturais que, uma vez entendidos como avisos divinos, dá ensejo a toda sorte de superstições e à sua instrumentalização política.

E é sob um ponto de vista político que desde os Pensées diverses até a Continuation e a Réponse Bayle vai refletir sobre a possibilidade de uma sociedade de ateus, reflexão decorrente do seu paralelismo entre o ateísmo e a idolatria e entre sociedades ateias e sociedades idólatras. À luz de suas conjecturas, Bayle estabelece uma separação entre a esfera religiosa e a esfera política, pensando "uma ordem política autônoma e propriamente humana distinta da anarquia" (DELPLA, 1999, p. 124). Nesse sentido, em vez de entender uma sociedade de ateus como uma mera ficção ou utopia da parte de Bayle, é mais interessante e profícuo pensar com o autor sobre as viabilidades concretas de um contexto político que não visa exterminar a religião, mas instaurar-se e consolidar-se independente dela.

Desde os tempos mais antigos religião e política sempre agiram juntas, a primeira sendo com um instrumento de temor espiritual, que inculca o medo e a esperança nos homens, e a outra, por sua vez, é que faz com que tais sentimentos sejam impostos ordinariamente dentre os homens e por meio de diversos artifícios visando à eficácia e o cumprimento dos preceitos religiosos na sociedade. Em suma, a religião é uma invenção humana colocada em prática pela política. Para tal constatação, Bayle recorre à história, isto é, à experiência:

Com receio de ser muito longo, não citar-vos-ei todos aqueles que disseram que os Políticos inventaram o culto aos Deuses a fim de manter os povos na dependência necessária. As pessoas que vós faleis que dizem em voz alta que a religião está entre as mãos dos Magistrados como o arreio nas mãos de um Cavaleiro que faz no cavalo todos os exercícios de manejo, têm aí aparentemente uma reflexão que se encontra em Políbio. Esse famoso Historiador declara que não há nada em que a República Romana pareçalhe ultrapassar os outros povos do que na opinião que ela tinha dos Deuses: de modo, ele continua, que isto que é censurado pelos outros homens, quero dizer, a superstição, é, o que me parece, o que mantém esta

9 Bayle diz na Réponse: "Por mais espantosa que possa ser a multidão dessas seitas, ela é o infinitamente menos do que a qualidade monstruosa de suas opiniões, que espalham no espírito uma desordem abominável, completamente vergonha à espécie humana e no coração uma corrupção abominável" (OD III [RQP III], p. 953b, tradução nossa). Sobre a alusão de Bayle a autores que sustentaram que o ateísmo não é a pior das opiniões, ver $C P D, \S \S L X X V I-L X X V I I$ e $\S$ CXLIII.

PRIMO, Marcelo de Sant'Anna Alves. Pierre Bayle e a reflexão sobre a imagem do ateu virtuoso na modernidade. Griot : 
República. A superstição aí é tão ultrajante e de tal modo espalhada não somente sobre a conduta dos particulares, mas também sobre a conduta pública, que não se saberia nada acrescentar, e penso que os Romanos fizeram isso por causa do povo. Porque se se pudesse formar uma República onde somente tivesse pessoas sábias, todas essas cerimônias de religião talvez seriam supérfluas, mas visto que o povo é inconstante e repleto de paixões injustas, que irrita-se subitamente e que a cólera o leva à violência, só resta freiá-lo por terrores invisíveis, e por esses tipos de ficções terríveis $(O D \operatorname{III}[C P D], \text { p. } 292 a \text {, tradução nossa })^{10}$.

O que seria a religião neste contexto? Uma invenção dos homens, que tem como único intuito freiar ou limitar as paixões humanas, devido à oscilação das mesmas, sempre suscetíveis de se aflorarem e culminar na violência. Recorrendo aos fatos históricos, Bayle afirma que a religião é um sério obstáculo para o estabelecimento de uma República sólida, independente de temores fictícios e apoiada unicamente em leis humanas. Equiparando a religião à superstição, Bayle mostra que houve um motivo especial para o seu surgimento: a volubilidade das paixões humanas ${ }^{11}$. Estas sempre instáveis, podem dar ensejo a ações deveras perniciosas à esfera social e precisam ser contidas. Por meio de cerimônias, rituais, orações, oferendas e sacrifícios, a religião se dissemina e cristaliza seus preceitos tanto no âmbito do particular, como tem a sua influência na esfera pública.

Nesse sentido, há uma diferença no que concerne às ações civis entre o ateu e o idólatra: se o primeiro, para agir retamente, não tem como parâmetro de conduta instância e mandamentos supraterrenos, tampouco tendo algo a esperar ou temer, o último tem como imperativo moral ficções invisíveis de inquestionável eficácia social e política, levando o indivíduo às últimas consequências. Na verdade, se a religião era pra ser um freio, na prática é o móbil dos comportamentos e das ações mais hediondas. Por isso, a "semelhança" entre uma sociedade de ateus e uma sociedade

\footnotetext{
${ }^{10}$ A religião como algo inútil, reduzida a um freio das paixões humanas era inaceitável, por exemplo, à Montesquieu: "Bayle pretendeu provar que era melhor ser ateu do que idólatra; ou seja, em outros termos, que é menos perigoso não ter nenhuma religião do que ter uma ruim. 'Eu preferiria', diz, 'que dissessem de mim que eu não existo a que dissessem que sou um homem mau.' É apenas um sofisma, fundado no fato de que não há nenhuma utilidade para o gênero humano que se acredite que um certo homem existe ao passo que é muito útil que se acredite que Deus é. Da ideia de que ele não é segue-se a ideia de nossa independência; ou, se não pudermos ter essa ideia a de nossa revolta. Dizer que a religião não é um motivo repressor, porque nem sempre ela reprime, é dizer que as leis civis tampouco sejam um motivo repressor. É pensar mal contra a religião reunir numa grande obra uma longa enumeração dos males que ela produziu, se não fizer o mesmo com os bens que trouxe. Se eu quisesse contar todos os males que as leis civis, a monarquia, o governo republicano produziram no mundo, eu diria coisas horríveis. Ainda que fosse inútil que os súditos tivessem uma religião, não o seria que os príncipes a tivessem e que mordessem o único freio que aqueles que não temem as leis humanas podem ter. [...] Para diminuir o horror do ateísmo, ataca-se demais a idolatria. Não é verdade que quando os antigos erguiam altares a algum vício isso significasse que amavam aquele vício; significava, pelo contrário, que o odiavam. Quando os lacedemônios ergueram uma capela ao Medo, isso não significava que aquela nação belicosa pedisse a ele que tomasse os corações dos lacedemônios durante os combates. Havia divindades para as quais se pedia que não inspirassem o crime, e outras a que se pedia que o afastassem." (MONTESQUIEU, 2000, pp. 466.467).

11 Segundo Delpla, “a superstição aparece, nos Pensées diverses, como a essência mesma do teológicopolítico, como a confusão de um pensamento que não distingue entre diferentes ordens. A crítica das práticas idólatras de divinização dos príncipes no Império romano, das cerimônias e das instituições pagãs é a de uma política que cede sua legitimidade a uma ordem religiosa"(1999, p. 124).
}

PRIMO, Marcelo de Sant'Anna Alves. Pierre Bayle e a reflexão sobre a imagem do ateu virtuoso na modernidade. Griot : 
de idólatras esvai-se, mesmo se Bayle intentou em seus Pensées diverses, em somente comparar o que teria de parecido entre ambas:

\begin{abstract}
Após todas essas observações, não terei dificuldade em dizer, se querem saber minha conjectura no tocante a uma sociedade de ateus, que me parece, a respeito dos costumes e das ações civis, que ela seria tal como uma sociedade de pagãos. Na verdade, precisaria de leis muito severas e muito bem executadas para a punição dos criminosos. Mas não é preciso em toda parte? (2007, p.161; OD III[PD], p.103b, tradução nossa).
\end{abstract}

Se a conjectura é a respeito da existência e viabilidade de uma sociedade de ateus, é fato que as leis humanas, seja em qual sociedade for, são o melhor artifício para a punição de crimes. A necessidade de um corpus de leis consistentes e eficazes é o que garante o bom funcionamento das relações sociais, deixando de lado imperativos de ordem metafísica ou religiosa que, ao invés de conterem as paixões humanas as inflamam ainda mais levando à transgressão das leis, e o pior, minimizam - ou mesmo suprimem - a legitimidade e a autonomia da política. Dessa forma, o que era semelhança torna-se uma distinção fundamental e o simples paralelismo fica para trás: aos ateus são suficientes as leis humanas, sendo dispensáveis recursos a superstições, crendices e a instâncias supraterrenas supostamente reguladoras dos mecanismos sociais. A contrario, aos idólatras, além das leis estabelecidas pelos homens, são necessários imperativos de ordem religiosa que nem sempre estão de acordo com as leis estatais. Bayle afirma: "Pode-se dizer sem bancar o declamador que a justiça humana é a eficácia da maior parte do mundo, porque desde que ela afrouxa o arreio a algum pecado, poucas pessoas se garantem" $(P D, 2007$, p. $341 ; O D$ III $[P D]$, p. 104a, tradução nossa).

Na Continuation, Bayle desenvolve um pouco mais essa questão. Ele afirma que por meio das leis humanas conservou nos indivíduos "as ideias de honestidade e o desejo de boa reputação" (OD III, p. 370a, tradução nossa). Uma vez ausentes as leis humanas, o caos se instalaria, pois os indivíduos exigiriam ou fariam justiça por si mesmos e sem se submeter a ordem alguma, o que provaria a necessidade de elegerem alguém para conter e punir perturbadores da ordem vigente. Entretanto, as leis não podem ter como espelho os deuses, mas serem estabelecidas e sancionadas unicamente pelos homens. Fazer leis tomando como exemplo entidades supraterrenas seria a ruína das noções de dever e de moralidade:

Os Filósofos, os Legisladores, os Magistrados, todas as pessoas esclarecidas
entre os Gregos, entre os Romanos sabiam muito certamente que essas
ações eram opostas aos deveres da moral e da vida civil, e que para bem
educar a juventude não precisaria propor-lhe como exemplo as Divindades
que se adorava publicamente, mas os homens sábios e virtuosos. Nada era
mais próprio para arruinar as Sociedades pela corrupção dos costumes que
a imitação desta espécie de Divindades (Id. Ibid., p. $370 b$, tradução nossa).

Bayle mostra que leis tendo como fundamento as ações dos deuses serão somente frágeis e imorais, e uma pedagogia também apoiada sobre preceitos religiosos também seria infrutífera. Se há a necessidade de basear-se em exemplos para que seja instaurado um corpo jurídico capaz de fazer leis e aplicá-las justamente aos transgressores, da mesma forma que, para educar os jovens, é mister separar o que é 
divino do que é humano em seu processo pedagógico, então que tais exemplos sejam humanos, da ordem do real, concretos.

O filósofo francês diz que os dois pilares sustentadores de qualquer sociedade são o pudor e a justiça (Id. Ibid.) e, ao mesmo tempo, ambos são repressores de qualquer ação maléfica. Se essas duas coisas são o que conservam a paz pública e reprimem o que há de injusto na sociedade, não é possível mais sustentar que a religião seja um agente limitador das paixões humanas:

\begin{abstract}
Se elas bastam a isto, são, com a mais forte razão, suficientes para manter as Sociedades irreligiosas; porque se se comete mais violentamente um crime quando aí se é levado, não somente como os Ateus pela segurança de que não irrita nenhum Deus, mas também como os Pagãos pela esperança da bendição dos Deuses os quais se tornam os imitadores, e que creem serem os árbitros de todos os bens da fortuna (OD III $[P D]$, p. 370b, tradução nossa).
\end{abstract}

Sob os auspícios das leis humanas e das noções de pudor e justiça, ateus e idólatras regrariam suas respectivas condutas e também seriam penalizados caso infligissem as leis estipuladas na esfera social. $O$ critério da crença individual não é mais cabível, pois o que será tido como justo ou injusto, honesto ou desonesto, bom ou ruim será avaliado de acordo com o cumprimento ou descumprimento de uma legislação vigente e válida para todos, sejam ateus ou idólatras. Em suma, um direito propriamente humano e concreto só terá a sua legitimidade, autoridade e eficácia quando deixar de lado critérios que nada têm a ver com a ordem dos fatos, isto é, não podendo limitar-se a ser uma ciência mimética, reprodutora da vontade e dos exemplos dos deuses ${ }^{12}$.

Por inúmeros exemplos, Bayle vai desconstruindo o que seria o paralelo entre o ateísmo e a idolatria. Nos Pensées diverses, quando ele indaga se uma sociedade de ateus poderia promulgar, para si mesma, leis de conveniência e honra, ele retoma a questão. O seu paralelo entre ateus e idólatras, por sua vez, é classificado como algo aparente, ilusório:

Vê-se a esta hora o quanto é aparente que uma sociedade de ateus
praticaria as ações civis e morais tanto como as outras sociedades as
praticam, visto que ela punisse severamente os crimes e que atribuísse
honra e infâmia a certas coisas. Como a ignorância de um primeiro ser
criador não impediria os membros desta sociedade de serem sensíveis à
glória e ao desprezo, à recompensa e à pena, e a todas outras paixões que
se vêem nos outros homens, e não sufocaria todas as luzes da razão, ver-se-
ia entre eles pessoas que teriam boa fé no comércio, que assistiriam aos

12 Neste sentido, Bayle menciona que o gênero humano deve muito à Filosofia, pois ela que inculcou e fortaleceu a ideia de honestidade nos legisladores: "Não quero terminar este capítulo sem fazer-vos ter em conta que o gênero humano teve grandes obrigações com a Filosofia. É ela que forneceu os Legisladores e que fortificou e estendeu as ideias da honestidade: confesso que sés preceitos não regravam as devoções populares, mas eles conservaram no espírito dos Magistrados o conhecimento da doutrina dos costumes, e se prevenia por aí as furiosas desordens que a Teologia fabulosa devia levar naturalmente. Não se podia reformá-la: a empreitada era périlleuse e poderia derrubar a República: precisar-se-ia contentar-se em prevenir o contágio do mau exemplo dos Deuses." (OD III $[C P D]$, p. 370 , tradução nossa). Sobre a comparação entre as leis humanas e divinas, iato é, qual impõe mais medo nos homens, ver Id. Ibid., §CXXXVIII.

PRIMO, Marcelo de Sant'Anna Alves. Pierre Bayle e a reflexão sobre a imagem do ateu virtuoso na modernidade. Griot : 
pobres, que opor-se-iam à injustiça, que seriam fieis a seus amigos, que desprezariam as injúrias, que renunciariam às volúpias do corpo, que não fariam nada a ninguém, seja porque o desejo de serem louvados levá-los-ia a todas essas belas ações que não deixam de ter a aprovação pública, seja porque o desígnio de se poupar dos amigos e dos protetores no caso que a necessidade aí os levasse $(2007$, p. 359; OD III $[P D]$, p. 109a, tradução nossa).

Aqui é claro o quanto Bayle eleva o ateísmo acima da idolatria. Longe de somente compará-los em seus aspectos filosóficos, morais e políticos, agora ele aponta as claras diferenças entre um e outro. Ignorar a existência de um deus não priva o ateu de fazer boas ações e Bayle cita algumas delas na passagem citada. Se os mesmos móbeis que levam um crente a fazer boas ações podem fazer com que o ateu faça as mesmas ações, então a existência de uma divindade moralizadora, que pune ou que recompensa, é irrelevante para a conduta humana ${ }^{13}$.

Bayle entrevê também o outro lado do problema: pois em uma sociedade de ateus também poderia ocorrer diversas atrocidades, já que são os mesmos móbeis de ordem interna e externa que o levam a agir:

Cometer-se-ia aí crimes de todas as espécies, eu não duvido; mas não faria
mais do que nas sociedades idólatras, porque tudo o que fez agir os pagãos,
seja para o bem seja para o mal, encontar-se-iam em uma sociedade de
ateus, a saber, as penas e as recompensas, a glória e a ignomínia, o
temperamento e a educação (Id. Ibid., pp. 359-360; Id. Ibid., p. 110a,
tradução nossa).

Os mesmos tipos de intempéries podendo ser constatadas em uma sociedade de ateus a coloca lado a lado com uma sociedade de idólatras: medo de ser punido, desejo de ser recompensado, fatores psicológicos e culturais. Contudo, em nada essa objeção desvalida o argumento de Bayle a favor do ateísmo, pois se a imagem clássica em sua época daquele que não crê é a de um monstro irracional, incapaz de agir pela reta razão, o filósofo de Carla simplesmente reverte tal opinião e coloca o ateu no patamar de um homem qualquer, não sendo melhor ou pior, mas um indivíduo que também pode agir movido por anseios e interesses, seja para o bem seja para o mal ${ }^{14}$. Vejamos essa passagem da Continuation:

Eu refutei isso, mostrei-vos que independentemente da Religião há no gênero humano um princípio suficiente para manter as Sociedades segundo a miscelânea de confusão que a experiência nos mostra. A Idolatria não tem nenhuma vantagem sobre o Ateísmo a este respeito, e assim, bem longe de ter merecido ser preferida, ela mereceria ser substituída (OD III $[C P D]$, p. 355b, tradução nossa).

é claro: se em todas as sociedades há um principio que as mantêm e as faz prosperar, não dependendo da religião, mais uma vez Bayle endossa a superioridade do ateísmo

${ }^{13}$ Pois trata-se da "acessibilidade dos valores morais do ponto de vista do ateu"(MORI, 1996, p.344).

${ }^{14}$ Cf. $P D, \S 144:$ "E estejais certo que, se o idólatra se encontra fornecido de um corpo que o torne extremamente sensível à boa carne, impudico, violento e orgulhoso, será incomparavelmente maior pecador do que um ateu de temperamento frio e pacífico" (2007, p. 308; OD III $[P D]$, p. 93a, tradução nossa).

PRIMO, Marcelo de Sant'Anna Alves. Pierre Bayle e a reflexão sobre a imagem do ateu virtuoso na modernidade. Griot : 
sobre a idolatria. A argumentação prudente dos Pensées diverses ganha agora um tom mais radical, colocando os termos da questão: se a religião nunca foi o principio unificador das sociedades, sendo um fenômeno que surgiu a posteriori, logo, a idolatria é algo inútil, dispensável em certas sociedades - senão em todas - e suscetível de ser substituída. Na verdade, a hipótese da sociedade de ateus é um factum, visto que "as sociedades são todas ateias e desde sempre. Em outros termos, que vivemos em sociedades ateias, isto é, que a religião jamais é constitutiva da vida social" (GROS, 2012, p. 256).

Bayle toca em um ponto específico nos Pensées diverses, a questão dos crimes de lesa-majestade. Neste tipo de crime, o idolatra supera de longe o ateu, já que só é conveniente ao devoto louvar sua divindade quando esta lhe contempla. E, por outro lado, o idólatra não hesita em imprecar contra os céus quando uma vontade sua não é efetivada. Nesta manifesta moral de interesse, o ateísmo não toma parte já que o ateu, não crendo em nada, não cometeria esta infração. Ele afirma:

\begin{abstract}
Mas se os idólatras somente igualam-se aos ateus na maior parte dos crimes, é certo que eles ultrapassaram no de lesa-majestade divina principalmente. Porque, além dos modos de falar insolentemente contra os deuses que se veem em seus livros sem que se veja que elas tenham feito negócios com o autor; que se vendo, digo, em grande número, não somente nos poetas, mas também nas obras em prosa, não se sabe que os pagãos degradaram suas divindades quando eles estavam descontentes? (PD, 2007, p.284; OD III $[P D]$, p. 84b, tradução nossa).
\end{abstract}

Falando injuriosamente aos deuses e não ficando contente quando suas divindades não o agradam, o temperamento do idólatra varia de acordo com o seu grau de satisfação com a dádiva celeste. Bayle menciona que tal postura é mostrada tantos nas obras dos poetas como nos escritos em prosa e menciona alguns exemplos Alexandre, o Grande, Augusto, os japoneses, os chineses - para mostrar que a idolatria muda de época e de lugar, mas continua com a mesma característica, isto é, elogiar ou execrar os deuses é questão de conveniência para quem crê. Segundo Bayle, quando um idólatra, por exemplo, demole um templo porque uma divindade deixou morrer um homem não fazendo justiça, ele entende que seu deus é injusto e uma vez não sendo contemplado com o julgamento divino, age por contra própria (Id. Ibid.) Bayle compara tal ação do idólatra como a de um político que tenha afastado seus ministros de seus cargos sem motivo algum, isto é, outorgar-se o direito de fazer algo por sua própria vontade.

A questão de Bayle é a seguinte: se o idólatra agisse coerentemente com seus princípios, não ficaria insatisfeito quando seu deus não agiu da forma que lhe fosse desejável, pois

[...] se ele não o faz, o homem está em direito de castigá-lo pela supressão das honras que lhes rendiam, como quando um príncipe pune seus servidores despojando-os de seus cargos? Não é crer que Deus é injusto e que se pode fazer-lhe afrontas impunemente? Em uma palavra, não é levar o desprezo e a insolência mais longe que jamais um ateu o fez? Um ateu não rende honras a Deus porque ele não é persuadido que ele existe. Se ele abate um templo, ele não crê ofender nenhuma divindade. Mas um idólatra que faz a mesma coisa recusa honras a um deus que ele reconhece,

PRIMO, Marcelo de Sant'Anna Alves. Pierre Bayle e a reflexão sobre a imagem do ateu virtuoso na modernidade. Griot : 
e as recusou-lhes a fim de ofender (Id. Ibid., p.286; Id. Ibid., p. 85b, tradução nossa).

Na escala de injúrias a um deus, o idólatra é infinitamente mais propenso a cometer crimes de lesa-majestade, pois, ao mesmo tempo em que crê, depsreza seus deuses quando destrói um reduto de homenagem ou quando profere declamações questionando o desígnio das ações divinas. A incoerência é manifesta, pois a recusa deliberada em conceder honrarias, motivada por sua insatisfação e revolta contra a sua divindade, faz com que o idólatra se eleve muito acima do ateu em termos de profanação e desprezo em relação aos deuses.

Na mesma linha de raciocínio, Bayle dá um exemplo de caráter político:

Suponhamos dois franceses o qual um não obedeceria nem a Luís XIV nem a qualquer rei que fosse, e o outro, desconhecendo o grande príncipe que Deus nos deu, reconheceria como o rei da França um homem de pouco mérito. Em vossa opinião, qual desses dois homens antes ofenderia o rei? Seria sem dúvida o último, porque, em caso de rebelião, o primeiro não é de recusar a obediência a seu príncipe legítimo, mas o cúmulo da felonia é colocar outro em seu lugar; e mais aquele que lhe substitui é destituído de mérito, mais ofende o príncipe a que se deve obedecer. Um rei que se vê destronar por seus súditos porque eles querem viver como republicanos se consola mais facilmente do que se vê-los escolher um outro monarca: porque, no segundo caso, eles testemunham que não é o ódio pela monarquia que os fez agir, mas o ódio particular que eles têm por seu soberano. Não é difícil por estas considerações conhecer os idólatras que, ao lugar de adorar o verdadeiro rei do universo, substituíram-lhe por um número inumerável de divindades quiméricas, foram mais injuriosos a Deus do que os ateus $(P D, 2007$, p. 287; OD III $[P D]$, p.86a, tradução nossa).

O exemplo de cunho político dado por Bayle mostra o quanto seria mais injurioso reverenciar um outro rei ao invés do legítimo, do que simplesmente negar a sua autoridade por divergências de ordem política, como por exemplo, não aceitar determinado regime governamental. A analogia feita por Bayle com o exemplo do rei é claramente alusiva ao exemplo da postura dos idólatras: se um rei é rejeitado por simplesmente não ser reconhecido por seus súditos, seria na escala de crimes algo menor, pois o que está em questão é o sistema de governo, não o governante em particular. Quanto ao segundo caso, constitui uma verdadeira incongruência. Se o rei e o regime monárquico são reconhecidos pelos súditos e estes se rebelam não contra o regime político propriamente dito, mas contra a persona do rei mesmo reconhecendo a sua autoridade soberana, simplesmente revoltam-se tentando colocar no trono alguém de menor capacidade para comandar um reino. Em outros termos, este último caso é o caso do idólatra: a recusa deliberada de uma autoridade reconhecida de antemão em nome de seus desejos e fins individuais. Se o ateu é criminoso por somente ignorar a existência dos deuses e não os tendo como modelo de conduta e imperativo moral, o idólatra está nos antípodas, pois mesmo crendo em suas divindades e homenageando-as com honrarias, age por interesse próprio quando lhe convém e despreza seu deus quando não é agraciado.

Na Réponse, Bayle volta à questão: a religião é a base das sociedades? Segundo o filósofo, uma objeção poderia lhe ser levantada, a saber, que é comum os 
políticos entenderem como uma "primeira verdade nas máximas do Estado, que a religião é a base da segurança pública e a coluna ou o fundamento das Sociedades."(OD III[RQP III], p. 952b, tradução nossa). Entretanto, à sua resposta já dada a tal objeção nas Additions, em 1694, Bayle acrescenta algo novo: os políticos não falaram dessa forma no tocante à religião em geral, mas somente em relação a que lhes pareceu boa, pois as outras doutrinas eram vistas como um câncer no seio do Estado, e somente "toleram-nas por pura necessidade ou por toda sorte de precauções" (Id. Ibid., tradução nossa). Faz-se necessário que eles entendam que a religião que eles adotaram, estabeleceram e que supuseram ser o liame indissolúvel da sociedade não seria suscetível de ser fragmentada, corroída internamente por inúmeras divisões, pois tal cisão acarretaria drásticas consequências políticas, pois não há "situação mais perigosa ao Estado, nem mais capaz de perturbá-lo do que quando se eleva das Seitas" (Id. Ibid., tradução nossa). Segundo Bayle, sempre haverá inconvenientes: se determinadas religiões são toleradas com uma condição privilegiada, surgirá o risco iminente dela querer se tornar igual ou superior às outras, culminando em diversos confrontos e dissidências. Se outras são absolutamente privadas de qualquer benefício do Estado, a tendência é se revoltarem contra os governantes, sempre tratando com rispidez algum estrangeiro quando seus dogmas são preponderantes em algum país vizinho. Sendo vítimas de um massacre, o ódio é instigado nessas religiões, deixando frágil o Estado e expulsando-as do território, o enfraquece mais ainda, pois sempre o sentimento de vingança será iminente da parte rechaçada. E forçando-os a professar exteriormente a religião vigente do Estado, o resultado é o aparecimento de inimigos em seus próprios domínios (Id. Ibid., p. 953a). Daí Bayle infere: "Seria fácil provar que a maior parte dos Políticos sustentando de um lado que o Estado não pode prescindir da Religião, sustentam, por outro, que só deve ter uma Religião" (Id. Ibid., tradução nossa). Os teólogos, por sua vez, facilmente aceitam tal ideia, entendendo que a diversidade de religiões é tanto um mal eclesiástico como um mal político, que tem de ser evitado quando e como puder.

Entretanto, a adoção por parte dos políticos de uma religião única dá margem à intolerância. Isto é, doutrinas menores nos Estados são proibidas de exercícios de religião exteriores, tornando-se enclausuradas em seus redutos de culto e não sendo toleradas pelos partidários da religião dominante. Nessa perspectiva, a tolerância nada mais é do que algo pernicioso ao Estado, não podendo sequer ser mencionada em contextos políticos de caráter ortodoxo. ${ }^{15} \mathrm{E}$ quais seriam os motivos da recusa em tolerar uma multiplicidade de doutrinas? Segundo Bayle, os políticos temem as lutas intestinas causadas pelos inovadores em religião, cujas divisões causariam uma ordem deveras devastadora sem proveito algum ao Estado. Cada seita se vira contra a outra, e o governante tem de voltar suas preocupações para sanar tais conflitos, deixando de lado forçadamente coisas mais importantes a fazer no que concerne à prosperidade de seu país. Daí Bayle retoma uma questão que lhe foi feita por Jurieu - seu preceptor e depois algoz implacável - e a lança para Jacques Bernard, isto é, era melhor viver em um Estado com uma parte considerável de papistas ardorosos comandadas por monges, ou por pessoas indiferentes à

${ }^{15}$ Bayle cita o exemplo dos Presbiterianos na Escócia.

PRIMO, Marcelo de Sant'Anna Alves. Pierre Bayle e a reflexão sobre a imagem do ateu virtuoso na modernidade. Griot : 
religião? Citando o exemplo da intolerância religiosa no Reino Unido, Bayle lança uma curiosa indagação a Bernard:

\begin{abstract}
Proporei uma questão semelhante ao Sr. Bernard. Se a peste tornasse desertas algumas províncias da Inglaterra, e que precisasse escolher para repovoá-las ou uma colônia de spinozistas ou uma colônia de Papistas, bem provida de Missionários pela Congregação de Propaganda, credes que o Parlamento da Inglaterra preferiria esta a aquela? Estou certo de que me responderá que não, e que seria o primeiro a condenar um Parlamento que ordenasse uma tal preferência. Não há Protestante na Inglaterra que não temesse mais problemas e mais desordens no governo, se a nova tribo fosse muito zelosa pelo Papismo, do que ela não se preocupasse nem com o Papismo, nem com nenhuma outra Religião" (OD III[RQP III], p. 954a, grifo de Bayle, tradução nossa).
\end{abstract}

Bayle não hesita em dizer qual "tribo" o parlamento inglês escolheria: sem dúvida, a dos espinosistas. Podem ser cogitados seus motivos: eles não temeriam punições nem recompensas, não se dividiriam em uma diversidade de seitas e não fomentariam guerras de religião. A alusão de Bayle ao papismo não é gratuita: o papismo é uma das religiões mais intolerantes, empreendendo conversões à força, devastando doutrinas menores e por que não, devido à sua própria condição de huguenote. Entretanto, Bayle desfecha também um duro golpe no protestantismo, mostrando a intolerância dos protestantes em relação às religiões pouco expressivas, mostrando que o elo comum em todas as doutrinas é a lógica da dominação, uma vez dominantes em um território qualquer ${ }^{16}$.

Prosseguindo em sua argumentação, Bayle chega a cogitar que os protestantes franceses prefereriam um rei spinozista a um rei católico, mas as razões são óbvias, pois a revogação do edito de Nantes em 1685 que quebrou o cumprimento de uma série de concessões feitas aos protestantes pelos católicos, somente instigou o ódio nos refugiados. Logicamente, eles aceitariam um rei que fosse ateu ou indiferente à religião do que serem governados por um rei de uma religião diretamente oposta e inimiga:

\begin{abstract}
Estou certo que de todos os Protestantes Franceses que foram banidos de sua Pátria não há, nem mesmo entre aqueles que foram menos maltratados pelos dragões, que não estejam prontos para assinar que valeria mais às Igrejas Reformadas da França ter um rei Spinozista, e o qual todos os outros Súditos teriam sido spinozistas, do que ter um Monarca cheio de zelo pelo Papado, e o qual a maior parte dos Súditos fossem animados do mesmo espírito. Efetivamente, se o Rei da França e todos seus outros súditos não tivessem tido nenhuma Religião, eles estariam pouco preocupados que os Huguenotes tivessem uma, visto que, no resto, eles fossem vistos afeitos ao Estado e perfeitamente submetidos às leis civis $(O D \mathrm{III}[R Q P \mathrm{III}]$, p. 954a, tradução nossa).
\end{abstract}

A preferência mencionada por Bayle dos protestantes franceses por um Estado no qual um rei fosse ateu e com súditos ateus a um Estado governado por um

\footnotetext{
${ }^{16}$ Bayle perde seu irmão Jacob, devido a este se recusar a se converter ao catolicismo. Quanto à crítica ao papismo, ver $O D$ II $[C P h]$, II, v, em particular, e sobre a crítica ao protestantismo $O D$ II [SCPh], cap. XXXI, ao final.
}

PRIMO, Marcelo de Sant'Anna Alves. Pierre Bayle e a reflexão sobre a imagem do ateu virtuoso na modernidade. Griot : 
papista ardoroso e dogmático e acompanhados de súditos com a mesma verve, nas entrelinhas, mostra uma coisa: o governo mais tolerante seria o regido pelo ateísmo. Em tal Estado, pouco importaria qual doutrina o cidadão faria parte, qual deus reverenciasse, qual dia fosse à igreja. O fundamental, e isso Bayle diz claramente, é que ele fosse obediente às leis estabelecidas pelo governante. Conforme a passagem citada, efetivamemente seria mais benéfico aos refugiados estarem sob os auspícios de um regime ateu, pois poderiam exercer seu direito de professar a sua religião e não se preocupar com oposições políticas temperadas por um sentimento religioso oposto e que está no poder.

Bayle cita a religião protestante, mas todas as religiões que respeitassem os limites estipulados pelo Estado, seriam toleradas não no sentido de serem meramente suportadas, mas com o pleno direito civil de optar por uma religião qualquer e exercê-la sem maiores preocupações de caráter doutrinal. Todavia, ele diz:

\begin{abstract}
Primeiramente, deveis considerar que quando há em um Estado duas Religiões as quais cada uma crê que a outra é inimiga de Deus e o grande caminho da condenação eterna, as animosidades se tornam tão grandes, que cada Seita imputa à outra de atrair sobre toda a Sociedade as maldições de Deus: a peste, a fome, as inundações, as tempestades, a perda das batalhas, etc. Então, a Seita que tem a orelha do Soberano não deixa de fazer-lhe protestos e de dizer-lhe que para fazer cessar esses flagelos de Deus, ele deve impedir que a heresia não seja mais pregada em seus Estados ou que a Idolatria aí não seja mais suportada. Ele render-se-á mais facilmente a esses protestos como será persuadido, com todos os Teólogos, que os Heréticos ou os Idólatras não estão, de forma alguma, de boa fé no erro, mas por um efeito de sua malícia. De modo que não é mais preciso desculpar suas blasfêmias e suas impiedades sob pretexto dos pretensos direitos da consciência, como os homicídios que cometidos por pessoas que estão ébrias. Que problemas, que desordens são a consequência de uma tal preocupação que jamais cairá no espírito de um Spinozista! (OD III[RQP], p.955ab, tradução nossa).
\end{abstract}

Bayle não deixa muita coisa para as religiões: toda e qualquer seita verá a outra como sua opositora direta, e o resultado inevitável é a desolação entre os homens em nome de um deus que não consegue ser definido por doutrina alguma. $\mathrm{E}$ se alguma seita dominante está próxima de um soberano influenciável, começará a conspirar contra tudo que lhe seja um entrave à sua dominação. A sociedade, por sua vez, ficará refém de infindáveis contendas religiosas de ordem teórica e prática, não conseguindo encontrar um apoio seguro que garanta a sua liberdade de consciência. Aqui, a crítica de Bayle não é restrita a uma seita em particular, mas todas passaram sob seu crivo: nenhum adepto de qualquer religião que seja erra inocentemente, mas é um erro calculado, visando a dominar e a aniquilar o opositor, caso seja necessário. O outro é um "flagelo", um errante, um idólatra ou um herético, todos incorrendo nos mesmos equívocos e todos carregando consigo mesmos o ódio e a vontade de dominação. E o espinosista? Este é a figura paradigmática do ateu virtuoso forjada por Bayle: é o que não destina suas preocupações a querelas de cunho doutrinário, é o esprit fort por excelência que sempre age pela reta razão, defendendo o direito da coexistência de seitas tão opostas umas às outras, o seu exercício é o da tolerância e

PRIMO, Marcelo de Sant'Anna Alves. Pierre Bayle e a reflexão sobre a imagem do ateu virtuoso na modernidade. Griot : 
que permite vislumbrar o binômio, agora longe de ser inconcebível, entre ateísmo e virtude.

O filósofo francês reduz ao âmbito do senso comum entender que uma sociedade não poderiar durar sem alguma religião, culto ou crença em uma divindade. E qual o suposto fundamento dessa opinião? Seria que uma vez erradicada o temor a uma providência divina e onisciente, punidora das más ações e recompensadora dos bons atos, todo tipo de atrocidades aconteceria no seio dessa sociedade. Todavia, Bayle apela à experiência:

\begin{abstract}
Mas que dizem eles quando lhes é alegada experiência incontestável, que nos ensina que os maiores crimes e que o abandono o mais extremo ao desregramento dos costumes reinaram entre os povos mais idólatras e, do mesmo modo, entre os Cristãos; o que prova que a Religião não reprime a perversidade do homem, e que é preciso atribuir a outros princípios a barreira que mantém as Sociedades? (OD III[RQP IV], p. 1057a., tradução nossa).
\end{abstract}

Contra a hipótese de que somente a religião poderia ser um freio em potencial para conter as mais inflamadas paixões humanas, Bayle recorre aos fatos: ao contrário, a religião foi justamente o estopim de tais paixões nas nações mais supersticiosas, que, imersas em sua depravação, não hesitaram em levar a cabo as ações mais abomináveis em nome de sua crença. Acreditar em uma providência divina é o que leva à instauração do verdadeiro caos no seio social, propagado pelo fanatismo e pela intolerância. A afirmação de Bayle é o diagnóstico absurdo, porém, verdadeiro, de uma sociedade que ainda insiste - e até hoje - em crer que a ameaça da intervenção dos deuses sobre a terra mudará a ordem das coisas e, daí, inferindo que a permanência de uma religião seja benéfica e de cunho inquestionável. Contudo, o suposto freio espiritual dos homens, sob a pena de Bayle, transforma-se no leitmotiv de intenções e de atos os mais inconcebíveis: conversões forçadas, obter riquezas materiais em troca de riquezas espirituais ${ }^{17}$, edificação de igrejas por todos os cantos do globo, combate às seitas de opiniões contrárias e aos ateus, fomentação da idolatria e da superstição.

Bayle lança as objeções de seus adversários contra eles mesmos: os que se dizem religiosos enveredam pelo caminho do vício por não estarem persuadidos das verdades de suas religiões, não crendo em uma providência e justiça celestes, e, por conseguinte, trilhando pelo ateísmo. Daí a conclusão: então não há fé que freie as paixões perniciosas e que assegure a moralidade dos costumes em uma sociedade, logo, não podendo ser designada como um liame social imprescindível. Nesse sentido, o filósofo de Carla mais uma vez fazendo vir à tona a experiência, arremata:

Eis aí uma doutrina que se sustenta somente por respostas que estabelecem o dogma contrário; porque se os homens viciosos são Ateus, as Sociedades as quais a maior parte dos membros são Ateus podem muito bem manterem-se. A experiência nos ensina que as Repúblicas e os Reinos onde a corrupção dos costumes foi mais prodigiosa durou por muitos séculos. Logo, é visível que se uma Sociedade onde há cem Ateus contra um homem que teme Deus pode manter-se, uma Sociedade toda composta

${ }^{17} \operatorname{Ver} O D$ II, [AAR], p. $608 a$. 
de Ateus também pode manter-se (OD III [RQP IV), p. 1057ab, tradução nossa).

Os próprios adversários de Bayle fornecem-lhe as próprias armas para refutá-los. Se os mais ortodoxos equivalem o ateísmo ao vício, a objeção pode ter o seu reverso, pois a experiência sempre mostrou que nas repúblicas e reinos - entenda-se, de religião católica, protestante, hebreus e maometanos - perduraram os maiores vícios e, ainda assim, conseguiram manterem-se firmes. Nesse sentido, eis a lógica de Bayle: se os ateus são viciosos, mas se os vícios sempre estiveram presentes nas sociedades religiosas, logo, uma sociedade composta somente de ateus poderia perdurar sem obstáculo algum. Evidentemente, Bayle não cede ao binômio ateísmo/vício formulado e tão defendido e disseminado pelos mais ortodoxos, mas somente seguiu as premissas de seus adversários e delas extraiu sua consequência lógica, voltando-as para eles mesmos. Todavia, o importante é que em todos os momentos diante de uma objeção, Bayle recorre tão e somente à experiência: esta mostra inquestionavelmente que a religião e a crença em um deus providencial jamais tiveram o poder de impedir, e mesmo de erradicar, o livre curso e as consequências funestas das paixões humanas dentre os homens. 


\section{Referências bibliográficas}

BAYLE, P. (2012) Euvres diverses. La Haye: Compagnie des Librairies, 1737, 4 tomes. Paris: Hachette BnF. . (1971) Oeuvres diverses. Paris: Éditions Sociales. (2004) Correspondance, Tome III. Publiées et annotées par Élisabeth Labrousse, Hubert Bost et alli. Oxford: Voltaire Foundation.

- (1994) Pensées diverses sur la comète. Paris: Société dês Textes Modernes. (2007) Pensées diverses sur la comète. Paris: Flammarion.

DELPLA, I., ROBERT, Ph. de. (Éd.) (2003) La raison corrosive: études sur la pensée critique de Pierre Bayle. Paris: Honoré Champion.

MONTESQUIEU, Charles de Secondat, Barão de. (2000) O espírito das leis. Trad. de Cristina Murachco. São Paulo: Martins Fontes.

MOREAU, P.- F. (1995) "Les sept raisons des Pensées diverses", In: Pierre Bayle: la foi dans le doute. Génève: Labor et fides, pp. 15-30.

MORI, G. (1996) "Baruch de Spinoza: athée vertueux, athée de système", In: Critique, savoir et érudition à la veille des Lumières: le Dictionnaire historique et critique de Pierre Bayle. Amsterdam \& Maarssen: APA-Holland University Express, pp.341358.

Autor(a) para correspondência: Marcelo de Sant'Anna Alves Primo, Universidade Federal de Sergipe, Av. Marechal Rondon, S/N, Rosa Elze, CEP 49100-000, São Cristóvão - SE, Brasil. marceloprimo_sp@hotmail.com 